\title{
OBITUARY
}

\section{Frederick ThOMAS TOOKe}

ThE many friends of Dr. Fred T. Tooke in Great Britain and in Europe will be sorry to hear of his death in Montreal on July 20, 1955. His happy, cheerful, good nature and camaraderie made him a host of friends wherever be went.

Frederick Thomas Tooke, one of Canada's most distinguished ophthalmologists, was born in Montreal in 1873. There he had all his schooling. At McGill University he graduated B.A. in 1895 and M.D., C.M. in 1899, after which he was an interne for 3 years at the Royal Victoria Hospital in Montreal. Then, on the advice of Dr. Frank Buller, he spent the following 3 years in Europe studying ophthalmology. During this latter period he served as clinical assistant in succeeding years under Professors Axenfeld of Freiburg and Morax of Paris, and under Sir William Lister and Mr. Marcus G. Gunn, at Moorfields, London. These were memorable years for him and he often spoke of them.

He returned to Montreal and opened his practice in ophthalmology. At this time he joined the staffs of McGill University and the Royal Victoria Hospital. He became Professor and Chairman of the Department at the former from 19371939, and Ophthalmologist-in-Chief at the latter from 1935-1940. Throughout a long professional life Dr. Tooke made many contributions to ophthalmic knowledge. These were mainly of a clinical nature. He will be remembered for his introduction of a cornea-splitting knife for use in the Elliot trephine operation. He carried on a very large and active practice in his specialty and only retired from it in 1950 .

He was a member and past president of the Montreal, the Canadian, and the American Ophthalmological Societies. He was also active in the Canadian Medical Association and the American Academy of Ophthalmology. He kept up his many European friendships through his membership of the Ophthalmological Society of the United Kingdom and the Societé d'ophtalmologie française.

In 1907 he married Katherine Moorcroft Tomlinson, who predeceased him in 1952; of this singularly happy union there were six daughters, all of whom survive him.

Mr. Harold Levy writes as follows:

To me, as a lifelong friend of Fred Tooke, the most outstanding features of his character were his invariable cheerfulness, his loyalty and conscientiousness.

He was happy in his work, happy in his family life, and happy in his friendships. It was always a pleasure and stimulus to be in his company.

He retired from practice in 1950 on account of increasing difficulty in concentration and speech, and the sudden death of his wife in 1952 left him completely helpless.

To those of use who knew him well his passing is a great loss and source of sorrow. 